International Journal of Instruction e-ISSN: 1308-1470 • www.e-iji.net
July $2018 \bullet$ Vol.11, No.3

p-ISSN: 1694-609X

pp. 433-448

Received: $24 / 11 / 2017$

Revision: 11/04/2018

Accepted: 16/04/2018

\title{
The Effect of Online Cooperative Learning on Students' Writing Skills and Attitudes through Telegram Application
}

\author{
Mojtaba Aghajani \\ Dr., Khatam ol-Anbia University, Tehran, Iran, mojtaba_aghajai45@yahoo.com
}

\author{
Mahsa Adloo \\ Vali-E-Asr University, Rafsanjan, Iran, mahsaadloo1371@gmail.com
}

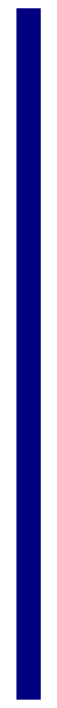

\begin{abstract}
The widespread of mobile devices bring a huge potential to e-leaning in terms of pervasiveness, ubiquity, personalization, and flexibility. In this study, a total of 70 university ESP learners were involved. Telegram, as the treatment in this study was compared to a conventional method; face-to-face in the cooperative writing activities. First of all a pre-test was administered to all students and based on the preliminary results; students were divided into Telegram and face-to-face Cooperative writing groups. After using both approaches, a post-test was given to participants. Then, a questionnaire was given to the students in order to investigate the effect of Telegram on the attitudes of ESP vocabularies and expressions by the ESP learners. The data were then analysed using independent $t$-test and paired sample t-test. From the findings, it was found that participants in Telegram Cooperative writing groups displayed slightly higher scores compared to face-toface Cooperative writing groups. However, the differences between Telegram and face-to-face Cooperative writing groups were not significant in the post-test writing scores. When comparison was made within each group, this study found that there were significant differences for overall writing performance, content, organization, vocabulary, language use and mechanics. The results also indicated that the students had positive attitudes toward using telegram Cooperative learning.
\end{abstract}

Keywords: cooperative learning, ESP course, telegram, mobile assisted language learning (MALL), attitude

\section{INTRODUCTION}

The current wide spread of mobile devices and wireless technologies bring an enormous potential to e-leaning in terms of pervasiveness, ubiquity, personalization, and flexibility. On the other hand, due to increased globalization and internationalization in recent decades, English has become the lingua franca of the world due to its widespread use in academia, electronics, commerce, and technology (Spolsky \& Shohamy, 1999).

Citation: Aghajani, M., \& Adloo, M. (2018). The Effect of Online Cooperative Learning on Students' Writing Skills and Attitudes through Telegram Application. International Journal of Instruction, 11(3), 433-448. https://doi.org/10.12973/iji.2018.11330a 
Moreover socialization has important pedagogical implications in mobile Cooperative learning by seeing mobile devices as mediated tools for collaboration that support the learners` relationships with their classmates (Caballe, Xhafa \& Barolli, 2010) Mobile devices have been recently used overtly because of their accessibility, ease of use, and popularity. On the other hand, the modern use of network and online applications has contributed a lot to online learning. More recently, the advent of the Internet also has enabled tremendous innovation in the delivery of post-secondary education (Gunasekaran, McNeil \& Shaul, 2002; Teo \& Gay, 2006).

Integrating other successful procedures of education with online learning, may prove useful and enhance learning outcomes. Cooperative learning and online learning both share the aspect of socialization in education. Shared learning enables students become autonomous and creative learners. Network based Cooperative activities ensures students for access to the peers and teachers and motivates them for better learning.

Telegram, as one of the most favoured social networking sites, has millions of users from primary schools to universities. On Telegram, people from all ages can create their own profiles, chat with each other and share their favourite photos and videos. It also has applications useful for teaching and learning. It is also a technological tool which can nurture the student-teacher relationship by creating positive learning experiences for both parties Cooperative Learning: The broadest definition of 'Cooperative learning' is that it is a situation in which two or more people learn or attempt to learn something together (Dillenbourg, 1999). It is sometimes referred as cooperative learning, collective learning, peer learning, reciprocal learning, or team learning. Whichever taken, the reference is to learning that involves students in working with others and, crucially, learning together. The outcome, therefore, should provide evidence of the nature of the Cooperative endeavour.

Writing is one of the most important tasks to be mastered by language learners that use language for electronics purposes whereas Cooperative writing per se, is one of the most important skills owned by electronics language users in order to authorize shared projects. Therefore, the present study has several purposes. First of all, the study is intended to identify electronics language learners ${ }^{\text {ee }}$ writing problems. It will investigate and identify ESP (electronics language) learnerse areas of problem in writing. Considering all of these we develop online problem solving material needed by electronics English learners for writing purposes. Writing is a complex activity, and as students enter the workforce, they will be asked to convey ideas and information in a clear manner. This increase in writing importance as well as the eventual writing skill development will allow the students to graduate with a skill that will benefit them for life (Alber-Morgan, Hessler, \& Konrad, 2007).

It is difficult to teach writing without using direct instruction (Walker, Shippen, Alberto, Houchins, \& Cihak, 2005). Even with direct instruction, writing requires that students draw on many skills at the same time. The student must write, think and compose, all the while using proper grammar and spelling (Kieft, Rijlaarsdam, Galbraith, \& van den Bergh, 2007). Some students are successful writers while others struggle with the written word (Penrod, 2007). 
In this sense, all types of writing errors will be regarded and addressed in materials that will be presented to the learners. The purpose of the study is to investigate the effects of Cooperative online learning via mobile applications (Telegram in this case) on writing skills of ESP learners. It is a general belief that writing is elusive and most language learners complain that despite knowing needed vocabulary and grammar rules, they are unable to write effectively. So the study is aimed to examine if online Cooperative learning can lead to a better application of skills. Moreover, the effect of using new technical model of providing educational material will be compared to the control group who receive this information via traditional model.

In summary, the study is mainly intended to examine the impact of online Cooperative learning via mobile applications (the independent variable) on writing skills (the dependent variables) among Iranian intermediate ESP (electronics language) learners.

\section{CONTEXT AND REVIEW OF LITERATURE}

Many of the studies that address content-related MALL activities appear to subscribe to a model whereby materials are delivered to learners via SMS or a website. Very few activities support learner collaboration or communication. While Dias (2002a, 2002b) promotes learner-learner interaction, of the work using more expensive mobile devices, only Southampton (JISC 2005) used MALL to encourage collaboration and coconstruction of knowledge; learners had to find information and share it with their peers in order to build up an overall understanding of a real-world problem, namely, the layout of the campus and the location and purpose of various buildings.

Thornton and Houser (2005) developed several innovative projects using mobile phones to teach English at a Japanese University. They also developed a course management system to facilitate developing language learning material to mobile phones. University of Wisconsin - Madison developed several foreign language courses which used wireless handheld computers for various classroom activities (Samules, 2003).

The advancements in mobile technology have also caused a lot of changes in the effectiveness of using mobile devices in language education (Baker \& Frank, 1992). City College, Southampton on developed a web-based "media board" (similar to a webboard) but supporting Multimedia Messaging Service (MMS) as well as Short Message Service (SMS) and supplied learners of English as a Second Language (ESL) with mobile phones, inbuilt cameras and voice recording facilities (JISC, 2005).

The major features of mobile learning, such as ubiquity, accessibility, flexibility, immediacy, interactivity, situating of instructional activities, are summarized and introduced by Ogata \& Yano (2005). Although there are several definitions, it is clear that not only technology but people also can be mobile. Viberg and Gronlund define mLearning as a "process of coming to know through conversations across multiple contexts among people and personal interactive technologies" (Sharples et al., 2010) with a focus on contexts.

The technology to assist in this process includes any kind of handheld mobile devices such as cell phones, personal digital assistants (PDAs), smartphones, pads, pods, etc. 
Ogata et al. (2010) state: "computer assisted mobile learning uses lightweight devices such as personal digital assistant (PDA), cellular mobile phones, and so on" (p.8). As mobile technologies provide many advantages flexibility, low cost, small size and userfriendliness, researchers are exploring how to use mobile technology to support language learning (Huang et al., 2012). Despite several shortcomings of MALL, Thornton and Houser (2005) show that mobile devices can indeed be effective tools for delivering language learning materials to the students. An overview of 20 years of mlearning has supported the fact that m-learning encourages social contact in interactional learning (Kukulska-Hulme \& Shield, 2008).

Students can learn the appropriateness of language in different situations. Some educators believe that language misuse is the fault of the students. Obviously there are cases where this is true, as well as cases where it is not. However, regardless of the situation, teachers can work to ensure that students develop a sense of audience when writing (Helderman, 2003).

To tie the advantage of adapting literacy education to the reality that electronic messaging is the dominant mode of written communication in the lives of many undergraduate students, educationalists can incorporate writing and electronic journals as they may improve students'ee writing skills (Raab, 2007). Teachers realize that when students are excited about their writing, they take more care with the final product (Rowen, 2005). New communicative applications such as Telegram should not be used just for the sake of wasting time and chatting. There has to be a goal that the teacher is trying to reach. It may help students in improving their writing products in a delightful way. Writing is one of the most important tasks to be mastered by language learners that use language for electronics purposes whereas Cooperative writing per se, is one of the most important skills owned by electronics language users in order to authorize shared projects. Therefore, the present study has several purposes.

It is a general belief that writing is elusive and most language learners complain that despite knowing needed vocabulary and grammar rules, they are unable to write effectively. So the study is aimed to examine if online cooperative learning can lead to a better application of skills.

The lack of change and reform in the conventional approaches to English language education is perhaps one of the reasons for the mentioned students' failures. The materials used by English language teachers and students are mostly confined to blackboard, the course book, and maybe some pictures. This is why the use of mobiletechnology might increase the Iranian students' motivation and increase their success in learning English as a foreign language. The present study, therefore, aims to implement a complementary teaching aid to solve the learners' writing problems.

The study was intended to identify electronics language learners'writing problems. It investigated and identified ESP (electronics language) learners' areas of problem in writing. Moreover, the effect of using new technical model of providing educational material was compared to the control group who received this information via traditional model.

In the light of the above-mentioned issues, the following research questions have been 
posed:

1. Is the online Cooperative Learning (via mobile applications) effective in the improvement of writing skills among Iranian ESP (electronics language) learners?

2. Do Iranian ESP learners have positive attitudes toward the application of Telegram social network in improving their writing skill?

This research aimed to evaluate the results of teaching writing by using telegram and makes a comparison between traditional methods and modern teaching by using social networks in English language teaching in Iran and to see if learners improve in speed and scores over time? And to see If social networking sites succeeded in both facilitating students' writing skill and also in increasing their motivations for learning English language, it can be suggested to be used as an effective educational material for improving the students' learning of English language, and also for changing the negative attitudes of many of the students toward learning English language as a difficult and in some cases an impossible task. This study also investigated students' attitudes towards use of social networking sites, Telegram in particular, in ESP courses.

\section{METHOD}

\section{Participants}

A sample of 70 male and female post-intermediate ESP learners will be selected using Quick Placement Test (Edwards, 2007), which is a general English placement test. This is done to assure the homogeneity of the participants considering their language proficiency. Then they will be divided into two groups, namely experimental and control groups.

\section{Instrumentation}

Quick Placement Test (QPT)

Quick Placement Test (QPT) was administered to monitor the subjects and homogenize them based on their level of proficiency.

\section{Course book national}

The course book used for both groups was "English for the Students of Electronics "(Babaie Zakliki, 2013). This book is one of the course books of the students of Electronics and is taught during one academic semester. This book has 15 units. Each unit is followed by different questions, an extra passage for translation and about 30 items for the students to write their Persian equivalent. This book is used in this study just for teaching electronics vocabularies to the students so that they have enough vocabulary knowledge to write.

\section{Social Networking Site}

Telegram was utilized in this study in Cooperative writing activities for ESP students in order to improve their English writing as well as evaluating their satisfaction. Telegram is currently one of the most used global social networking websites. The participants were required to join Telegram groups created by the researcher called "Enjoy English Writing". 
The primary features of Telegram, including "info", "friends", "like", "unlike", "comment", "send message", "share photos", "links", and "video" provide users with a variety of means to communicate and interact with each other and to make new friends all over the world. In particular, the "share status" feature plays an important role in Telegram activities.

People can almost instantly discuss and share all types of information and knowledge through the share status function, which is similar to an online discussion board. Student interactions in online discussions can facilitate a learner-centered approach to teaching and provide students with an opportunity to practice and learn knowledge and skills in a supportive and encouraging environment (Stacey, 2002; Birch \& Volkov, 2007; Moore \& Iida, 2010).

Pre-test

At the beginning of the educational semester, a pre-test (T1) was administered to the students of the two groups. The pre-test was administered without any previous announcement and the aim was determining the students' knowledge of the new vocabularies and their writing ability before the beginning of the treatments. It consisted of 10 words which the students should write their Persian equivalents and 5 questions which for each of them, the students were assigned to write at least four sentences. The participants were given 30 minutes to respond to all items. Finally the reliability of the test was examined using Cronbach`s Alpha formula which in this case is .89. This value is above .7, which indicates a certain level of consistency among the items in the instrument.

Post-test

The immediate post-test (T2) was administered to the two groups one day after the last treatment session. The post-test consisted of 10 questions in which students should write one paragraph for each question. The questions were designed on the basis of the passages which were taught in the classes and by Telegram. The participants were given 30 minutes to respond to all questions for each test. The students' writing was evaluated based on grammar, vocabularies, spelling and punctuation.

\section{A Survey Questionnaire}

In order to investigate the experimental group students' attitudes toward the use of Telegram in language learning, a semi structured interview was also developed in the respondents' mother tongue, Persian, to ensure their full comprehension of the items and prevent any language barriers and it was administered to the experimental group students at the end of the treatment sessions. The researcher examined closely the reliability of the interview by the use of Cronbach ${ }^{e e}$ alpha ${ }^{e e}$ formula in a pilot study.

\section{Procedure}

In the first step, one of the recent versions of Quick Placement Test was administered to the population of the participants out of whom 70 intermediate participants were selected. Levene's test of equality of error variances was employed and the obtained results on the assumption of homogeneity of variances indicated that the data have met the assumption $(p>.05)$. After making sure about the homogeneity of the participants, 
they were divided into two groups: experimental and control groups. Teaching writing skills and assigning different writing tasks were done to the experimental group through online Cooperative learning via mobile application (Telegram) and to the control group using traditional classroom teaching techniques. Online mobile application is a virtual spot in which teachers use activities to support participants' writing problems. At the beginning of the study, participants received the pre-test. It consisted of 10 words which the students should write their Persian equivalents and 5 questions which for each of them, the students were assigned to write at least four sentences. The participants were given 30 minutes to respond to all items. The questions were as follow:

1. Are ESP courses important in your academic achievement?

2. What is Electronics Management?

3. What is the role of writing skill in English language learning?

4. How often do you have electronics writing?

5. How important is writing in electronics success?

Their responses were analysed based on abbreviation, capitalization, acronyms, Bad grammar, poor spelling, wrong use of small letters symbol and other forms of text communications. The experimental group made a profile on Telegram.

The course book was taught to two groups so that students have the required vocabulary knowledge to do their writing activity. Then teacher explained sentence and paragraph writing to the students. Control group did their writing activity on paper and in the classroom every session. Teacher corrected their writing and gave oral and written feedback to the students.

Teacher created a new group on Telegram (Enjoy English Writing) and invited and added students to the group. Students of the experimental group received instructions about following the rules of online Cooperative learning. Writing assignments were then posted on Telegram for the students to practice writing and giving comments for eight weeks. All of the sentences were based on passages and vocabulary in the students' course book "English for the Students of Electronics Administration" (Babaie Zakliki, 2013). For each writing assignment, every student was required to post his or her own writing and comment on the works of others. The instructor encouraged the students to discuss, interact, and comment on other studentse works as much as they could. The students were also encouraged to share knowledge and ideas related to the writing assignments.

During this period, the instructor served as a facilitator and monitor evaluating and commenting on students" work and responses. From Week 4 to 8 , the instructor required all of the students to write a short composition every week on their group and to comment on others"e writings. A total of four writings were assigned. Additionally, some comments would be added followed by emoticons .For example, if someone made an error in their writing, a peer could make a comment with "@@" to show they were confused or speechless, or they could follow a comment with ":-D" to show they were happy with the writing or to provide encouragement. Based on the content analysis of the students" comments on Telegram, the most frequently used emoticons were categorized into two types: appreciative or encouraging emoticons and sad or 
questioning ones. Among the various emoticons used by the students to assist in commenting on other members ${ }^{\text {ee }}$ writings, some were encouraging and some indicated being sad or sorry. For instance, when students receive "like" from others, they may be motivated and feel more confident. On the other hand, the sad or sorry emoticons might hurt a recipient's feelings. Therefore, the students not only gave comments to others but also added more positive emoticons to soften the tone of texts to make them more polite. Therefore, the students could benefit from peer comments and feedback without harming their friendships and relationships. All group members were required to post their writing assignments on Telegram, assess the writings of other group members, and then provide them feedback and comments on Telegram weekly. All participants were also required to review and comment on other group members ${ }^{\text {ee }}$ feedback.

The control group did not use any social networking site and just studied their course book in the classroom with the students of experimental group. They were taught electronics passages every session and answered the following questions. At the end of the treatment, the post-test was run. The participants were given 30 minutes to respond to all questions for each test. The students' writing was evaluated based on grammar, vocabularies, spelling and punctuation.

The researcher also adopted a 5-point Likert scale survey questionnaire initially developed by Hsieh (2010) and then modified and re-named it "Blended English Writing Course Satisfaction (BEWCS)." The modified questionnaire was validated by two senior professors in the field to establish its content and construct validity. Responses to the questionnaires were collected and computed by SPSS descriptive analysis. Content analysis was used to analyse the students ${ }^{\text {ee }}$ writings, feedback, and comments on Telegram.

\section{FINDINGS}

All the collected data through scores of the so called tests were analysed. The data analysis was carried out by using SPSS. It should be noted that the validity and reliability of the teacher-made tests was established through statistical analyses and feedback from experts in the field.

Table 1

Population's age

\begin{tabular}{lccc} 
Participant's age & $18-20$ & $20-21$ & $21-23$ \\
\hline $94.3 \%$ & $3.8 \%$ & $1.9 \%$
\end{tabular}

The table 1 showed the population's age. There were $94.3 \%$ of populations during 18 20 years old, $3.8 \%$ of population during $20-21$ years old and $1.9 \%$ of population during 21-23 years old. There were not students during over 23 years old.

Table 2

Population's sex

\begin{tabular}{ccc}
\hline Participant's sex & Male & Female \\
\hline & $9.4 \%$ & $90.6 \%$ \\
\hline
\end{tabular}

The table 2 showed the population's sex. $90.6 \%$ of populations were female and 9.4 of Populations were male respectively. 


\section{Addressing the First Null Hypothesis}

In order to test the first null hypothesis, the post-test performances of the two groups, that is, the control group and the experimental group were compared to see if there was any significant difference.

Table 3

Post-test Results of English writing between face-to-face and telegram collaborative writing groups.

\begin{tabular}{|c|c|c|c|c|c|}
\hline Post-test & Method & Mean & SD & $\mathrm{t}$ & $\mathrm{p}$ \\
\hline \multirow[t]{2}{*}{ Content } & Face to face & 23.67 & 2.36 & \multirow[t]{2}{*}{1.213} & \multirow[t]{2}{*}{.234} \\
\hline & telegram & 24.59 & 1.94 & & \\
\hline \multirow[t]{2}{*}{ Organization } & Face to face & 16.09 & 1.46 & \multirow[t]{2}{*}{1.138} & \multirow[t]{2}{*}{.264} \\
\hline & telegram & 16.63 & 1.24 & & \\
\hline \multirow[t]{2}{*}{ Vocabulary } & Face to face & 15.06 & 1.57 & \multirow[t]{2}{*}{.392} & \multirow[t]{2}{*}{.698} \\
\hline & telegram & 15.34 & 2.14 & & \\
\hline \multirow[t]{2}{*}{ Language use } & Face to face & 16.74 & 2.58 & \multirow[t]{2}{*}{.302} & \multirow[t]{2}{*}{.765} \\
\hline & telegram & 17.00 & 2.47 & & \\
\hline \multirow[t]{2}{*}{ mechanics } & Face to face & 3.11 & .38 & \multirow[t]{2}{*}{1.752} & \multirow[t]{2}{*}{.090} \\
\hline & telegram & 3.38 & .47 & & \\
\hline \multirow[t]{2}{*}{ total } & Face to face & 74.71 & 7.59 & \multirow[t]{2}{*}{.867} & \multirow[t]{2}{*}{.393} \\
\hline & telegram & 76.94 & 7.18 & & \\
\hline
\end{tabular}

In Table 3, the independent t-test of the post-test scores indicated that there was a significant difference between face-to-face and Telegram Cooperative writing groups in terms of content, organization, vocabulary, language use as well as mechanics. Additionally, in terms of overall writing performance, there was also a significant difference between face-to-face Cooperative writing group and Telegram Cooperative writing group.

Table 4

Comparison of Pre-test and Post-test Scores of Overall Writing Performance for Faceto-Face Cooperative writing groups

\begin{tabular}{|c|c|c|c|c|}
\hline Face to face & Mean & SD & & $\mathrm{p}$ \\
\hline Pre-overall performance & 65.03 & 10.27 & \multirow[t]{2}{*}{-3.52} & \multirow[t]{2}{*}{.003} \\
\hline Post-overall performance & 74.71 & 7.59 & & \\
\hline Pre-content & 19.56 & 2.66 & \multirow[t]{2}{*}{-5.69} & \multirow[t]{2}{*}{000} \\
\hline Post-content & 23.68 & 2.36 & & \\
\hline Pre-organization & 14.32 & 2.42 & \multirow[t]{2}{*}{-2.74} & \multirow[t]{2}{*}{.014} \\
\hline Post-organization & 16.09 & 1.46 & & \\
\hline Pre-vocabulary & 13.09 & 2.41 & \multirow[t]{2}{*}{-3.54} & \multirow[t]{2}{*}{.003} \\
\hline Post-vocabulary & 15.09 & 1.57 & & \\
\hline Pre-language use & 15.12 & 3.05 & \multirow[t]{2}{*}{-1.73} & \multirow[t]{2}{*}{.102} \\
\hline Post-language use & 16.74 & 2.56 & & \\
\hline Pre-mechanics & 2.94 & .48 & \multirow[t]{2}{*}{-2.56} & \multirow[t]{2}{*}{.138} \\
\hline Post-mechanics & 3.12 & .38 & & \\
\hline
\end{tabular}

In Table 4, there were significant differences before and after intervention for the faceto-face Cooperative writing groups in overall scores, content, organization and vocabulary. However, for the language use and mechanics, there were no significant 
differences because the significant values $p>.05$.

Table 5

Comparison of Pre-test and Post-test Scores of Overall Writing Performance for Telegram Cooperative writing groups

\begin{tabular}{|c|c|c|c|c|}
\hline Face to face & Mean & SD & & $\mathrm{p}$ \\
\hline Pre-overall performance & 66.66 & 9.11 & \multirow[t]{2}{*}{-6.86} & \multirow[t]{2}{*}{.000} \\
\hline Post-overall performance & 76.94 & 7.18 & & \\
\hline Pre-content & 20.47 & 2.98 & \multirow[t]{2}{*}{-8.04} & \multirow[t]{2}{*}{000} \\
\hline Post-content & 24.59 & 1.94 & & \\
\hline Pre-organization & 14.69 & 1.86 & \multirow[t]{2}{*}{-5.73} & \multirow[t]{2}{*}{.000} \\
\hline Post-organization & 16.63 & 1.23 & & \\
\hline Pre-vocabulary & 13.97 & 2.06 & \multirow[t]{2}{*}{-3.08} & \multirow[t]{2}{*}{.008} \\
\hline Post-vocabulary & 15.34 & 2.14 & & \\
\hline Pre-language use & 14.63 & 2.87 & \multirow[t]{2}{*}{-3.30} & \multirow[t]{2}{*}{.005} \\
\hline Post-language use & 17.00 & 2.47 & & \\
\hline Pre-mechanics & 3.03 & .56 & \multirow[t]{2}{*}{-2.71} & \multirow[t]{2}{*}{.016} \\
\hline Post-mechanics & 3.34 & .46 & & \\
\hline
\end{tabular}

In Table 5, from the paired sample t-test analysis, it was found that there were significant differences in terms of overall performance as well as five components of Jacobs et al. (1981) ESL Composition Profile. This indicates that Telegram Cooperative writing group had improved students writing performance after the intervention. However, Telegram Cooperative writing groups obtained higher scores compared to face-to-face Cooperative writing groups.

This shows that social networking platforms like Telegram increased students`writing ability and helped them performed better (Roberts, 2009; Thanawan and Punchalee, 2012; Hatime \& Zaynep, 2012; Wichadee \& Nopakun, 2012) compared to face-to-face method. Blattner and Fiori (2009) emphasizes that authentic language interaction can be achieved via the interaction in Telegram which boosts students ${ }^{\text {ee }}$ confidence level and improve their English language performance.

Learners were allowed to express themselves in a more expressive manner without worrying about committing language mistakes (Nadzrah \& Mickan, 2003). With proper planning in educational project, English language learning could be established through Telegram (Kabilan et. al 2010). Telegram also believed to be an ideal place for learners to be surrounded by the language (Pasfield- Neofitou, 2011).

\section{DISCUSSION}

In this study students attended an introductory session during the first week of the semester to ensure that they were all familiar with the functionalities of their mobile phones and/or Telegram. As far as student-generated content was concerned, the current paper draws out what the learning context offered to students in ways that allowed them to create meaningful learning resources via their daily interaction with the external environment. Student-generated learning content did not only support collaboration and a community of practice among students, but it also fostered their individual creativity and competitiveness. Kukulska-Hulme et al. (2007) describe such user-generated 
activity as mobile-based cultural citizenship activity, in which students involve everyday life situations in their learning and transform that into engaging learning experiences. The contextualization of this language learning setting helped students to develop more sophisticated skills beyond the learning task itself. For example, students learnt how to think critically about certain issues and to justify local incidents particularly in the target language. Each student was required to analyze what his classmates wrote to Telegram and to find strong connections between in- class and out-of-class activities. Above all, students ${ }^{e e}$ decision-making skills improved by enabling them to provide critical feedback on the learning design, and allowing them to see the influence of their feedback and reflection on the adjustment made on the design. Results of post-test confirm that being part of the Telegram Cooperative learning is indeed for ESP students to improve their writing. This trend has been identified by many researchers and academics (see Oduor, 2010; Kolek, \& Saunders, 2008; Bugeja, 2006. Students in this study are active users or members of Telegram and they login daily, weekly or monthly. Hence, for a fluid data analysis and meaningful data interpretation that contribute to the discussions of Telegram as an online learning environment, we presented the mean scores supported by the qualitative data to provide a more balanced understanding of students' perceptions and practice on Telegram. The students demonstrate their ability to assimilate into the sociocultural practices of their respective Telegram communities, gain knowledge/skills and engage in written dialogues and conversations with them.

Via such interactions between teacher and students a "neo-apprenticeship style learning, similar to that proposed by Vygotsky, can occur" (Gannon-Leary, \& Fontainha, 2007, p.3). To obtain more in-depth information on the implementation of Telegram integrated blended learning for the English writing course from the participants, six students participated voluntarily in an interview. The six students"e responses to the three interview questions were carefully recorded and coded by the researcher. A summary and some selected extracts from the students ${ }^{\text {ee }}$ responses to the three questions are presented below.

1.What do you think of the course arrangement and implementation of the integrated Telegram blended learning approach for the English writing course?

All of the students indicated that the most important factors for them to be motivated to learn English writing and find the class interesting were the instructor's teaching techniques, teaching enthusiasm, and sense of humor, which corroborated the statistical results of the high mean scores on survey questions 1 to 3. Additionally, four students indicated that using Telegram in the English writing course was beneficial and helpful for them to learn English writing and to exchange opinions and ideas. Four students suggested that peer assessment could assist them in learning English writing and improve their writing skills. Finally, all of the students agreed that combining Telegram and peer assessment with the face to face instruction was an interesting and effective way for them to learn English writing. Excerpts of the students ${ }^{\text {ee }}$ interview responses are as follows:

A. like the teaching way of class, the teacher uses an interesting way to teach us.

B. Telegram is convenient for each group to write paragraph on it... it's meaningful 
because members can exchange opinion.

2. What are the advantages and disadvantages of using Telegram to assist in learning English writing?

Regarding the advantages of using Telegram to assist in learning English writing, some students indicated that they were able to find writing mistakes and to correct them on Telegram.

Additionally, it was much easier for them to learn from each other through posting writings on Telegram Moreover, using Telegram to do assignments was convenient and reduced stress and environmental impact. Finally, using Telegram improved teamwork.

However, the students also pointed out some disadvantages of using Telegram to learn English writing. Some reported that they sometimes forgot to do writing assignments on Telegram because they had too much fun on the Internet. Students also pointed out that writing online may result in bad habits with regard to vocabulary and spelling because they rely on the online correction tools too much.

Some students also argued that they were not able to communicate well with their group members on Telegram and that it was not easy to write clear view points or make clear comments on others' work because of the limitation on the number of characters on Telegram message board and limited English ability. Excerpts of the students" responses to Question 2 are as follows:

a. By using Telegram, I can learn the writing skills by reading my partner's essay...I think the way of discussing with members is very helpful for me.

b. We can read others"e paragraphs and learn others" good points...we can also discuss some writing skills.

3. What are the advantages and disadvantages of using peer assessment to learn English writing? The majority of the students suggested that their peer's comments on and assessments of their English writing were very useful and beneficial. However, two students pointed out that some group members sometimes commented on their writings incorrectly because their understandings of grammar and sentence structure were not correct.

This result is in accordance with the researcher's observations and experience in reviewing and commenting on the students" feedback on Telegram. I can know which part of writing skills I should improve... I will examine my paragraph carefully in order not to make too many mistakes.

(S5) I can find my wrong grammars because of their comments...it can improve my English skill. From the interaction, we can know others"e opinions to improve my writing. (S6) I can find my fault, and I can also correct other classmates" paragraphs... I can learn more vocabularies, grammars from them. (S2) Occasionally, the researcher found that some students made incorrect corrections to others ${ }^{\text {ee }}$ writings. Thus, this danger of using peer assessment in English writing courses should be taken into account.

To conclude, according to the studentse responses to the interviews, using Telegram and peer assessment to assist in learning English writing for students seemed to be a suitable approach for ESL teachers. Telegram provided the students with opportunities to assess 
others $^{\text {ee }}$ writings and improve their grammar, structure and content, organization, and vocabulary. Peer assessment tasks were regarded as learning exercises in this study, and the students had greater opportunities than the instructor to observe their peers through this learning process and to obtain knowledge and skills from the writings, comments, and feedback of others.

Furthermore, in the process of reviewing and commenting on their peers ${ }^{\text {ee }}$ work and offering comments and feedback, the students were able to modify their original work and improve its quality (Tsai \& Tseng, 2007). Thus, online peer assessment provided the students with additional chances to construct and refine their knowledge and skills through social interactions in a virtual environment.

These findings are also consistent with the principle of social constructivism that meaningful interactions in a learning environment enhances sharing perspectives and experiences in communities of practice (Birch \& Volkov, 2007; Woo \& Reeves, 2007; Wilson \& Stacey, 2004; Vygotsky, 1978).

It is worth noting that false corrections by peers could be detrimental to peer assessment activities for an English writing course.

Instructors should be aware of this issue when implementing peer assessment components in a course. The success of this blended learning course combining Telegram and peer assessment relied not only on a proactive course instructor involved and engaged in the students' comments and feedback, but also the students ${ }^{\text {ee }}$ full participation in the online writing activities. Telegram provided an excellent platform for displaying course information and a variety of resources for students to access freely. Its popularity, accessibility, and unique features attracted the students and eased their resistance to learning, making this a successful course.

To avoid students' resistance to peer assessment, instructors may have to provide a training session and appoint a group leader to guide and assist the teaching and learning interaction.

Additionally, instructors of English writing courses should be willing to spend a substantial amount of time checking and correcting studentse assignments and online peer comments. The major limitation of this study was the relatively small number of participants $(n=23)$. Future studies should involve larger numbers of students to be able to generalize the results. It would also be interesting to compare the effects among solely online instruction, Telegram-integrated blended learning, and face to face instruction of English writing courses. As the development and proliferation of Web 2.0 technologies make people more connected and provide access to more resources and information, investigating more effective strategies for English writing instruction becomes increasingly important for ESL and ESP educators.

\section{CONCLUSION}

Using Telegram will allow university ESP instructors to add writing to their subject matter across the curriculum while helping their students to improve their writing skills at the same time.

Telegram is a tool that significantly helps students develop their writing and improve the 
vocabulary word choice in their writing. Instructors could spot students that need work in improving the specific skills of writing and vocabulary word choice and incorporate Telegram into an individualized assignment for them to help improve those skills.

Overall, it can be said that students" writing performance was improved with the use of Telegram in Cooperative writing. With Telegram, more meaningful learning environment can be created and comment feature makes the learning process more easy and fun. Telegram also allows students to discuss with peers, give feedback and comment on the writing activities either synchronous or asynchronously.

In light of the results of this study, university ESP instructors need to be aware that Telegram can be an effective method of helping their students to improve their writing scores. English language instructors in Iran need to be aware of the implications of this study because it will give them options in teaching their students to write. Moreover, as this was a short term study, there is a need for a longitudinal study looking at the development of writing skills over a longer period of time, following students for at least one year but possibly four years, while they complete undergraduate level coursework.

In a brief suggestion, although this research is completed, there are many interesting points to do the future research. And this research is only the first step to receive the basic data about the population. This will lead to create next lessons for them to practice English though Telegram.

Using Telegram as a medium for language learning actively encourages a Cooperative environment, builds positive attitudes, increases motivation and student participation, and sustains teacher-student relationships (Mazer, Murphy \& Simonds, 2007). The teacher can promote the use of this social networking site by encouraging students to create Telegram accounts and add their teacher and classmates as friends. He or she can be updated on the assignments, upcoming events, and other pedagogical information on Telegram.

Similar to most research, this paper has limitations that point to further opportunities. The authors focused on only five out of the numerous tertiary institutions in Ghana. Additional studies on other students in other universities should provide further insights into the impact of telegram on the performance of ESP students. Simply stated, we found the claim that Social Networking site was addictive and effective,, to be misleading. Though we saw its potential, and understand that current theory in language acquisition calls for social interactions, we certainly did not feel a need to return to the site day after day. This research has exposed a number of areas that could provide the stimulus for further consideration within scope of social networking online language learning.

While this study was performed on a single case, a similar study, utilizing diary studies could be performed with multiple cases in which participants are each learning another language. An investigation into the themes that arise from having various perspectives would provide further scope to the results found here.

This research has found that in order to create an online learning environment, in which the learner is able to interact with the site and other people, there are a great many considerations to be aware of, especially before delving into the complexities of 
language. This research highlights the importance of design, incorporating the pedagogical needs of the learner and a detailed understanding of the language to be used for communication within a social networking site. The current study was constrained by two factors. First, due to time constraints, the survey was administered mostly to a convenience sample. Therefore, the sampling of the participants may not be adequate for valid statistics that truly reflect the actual capacities and perspectives of the students towards the MALL approach in English learning in Iranian ESP context. These findings may be beneficial for stakeholders, educators or writing instructors to utilize Cooperative writing in Telegram especially to harness writing skills and change students ${ }^{\text {ee }}$ perceptions that Telegram is actually appropriate to be medium for English learning. Besides, this study also is hoped to make them to see the connection between the meaningful communicative use outside of the classroom and writing activities that were conducted in a formal setting like classroom context.

\section{REFERENCES}

Alber-Morgan, S.R., Hessler, T., \& Konrad, M. (2007). Teaching writing for keeps. Education and treatment of children 30, 107-128.

Baker, C. \& Frank, B. (1992). Item Response Theory: Parameter Estimation Techniques. New York: Marcel Deker.

Birch, D. \& Volkov, M. (2007). Assessment of online reflections: Engaging English second language (ESL) students. Australasian Journal of Educational Technology, 23(3), 291-306. http://www.ascilite.org.au/ajet/ajet23/birch.html.

Bugeja, M. J. (2006). Facing the Facebook. The Chronicle of Higher Education, January, 27, C1.

Caballé, S., Xhafa, F., \& Barolli, L. (2010). Using mobile devices to support online collaborative learning. Mobile Information Systems, 6(1), 27-47.

Dillenbourg, P. (1999). What do you mean by Cooperative learning? Collaborativelearning: Cognitive and Computational Approaches. 1-19.

Gannon-Leary, P., \& Fontainha, E. (2007). Communities of practice and virtual learning communities: Benefits, barriers and success factors. eLearning Papers, 5,1-14.

Gunasekaran, A., McNeil, R. D., \& Shaul, D. (2002). E-learning: research and applications. Industrial and Commercial Training, 34(2), 44-53.

Hatime, C., \& Zeynep, K. (2012). Effects of Peer E-Feedback on Turkish EFL Students' Writing Performance. The Journal of Educational Computing Research, 46(1), 61-84.

Helderman, R.S. (2003, May 20). Click by Click, Teens Polish Writing; Instant Messaging Teaches More Than TTYL and ROFL. The Washington Post, p. B.01.

JISC (2005). „Multimedia learning with mobile phonese. Innovative Practices with Elearning. Case Studies: Anytime, any place Learning. Accessed 27 August 2007 from: http://www.jisc.ac.uk/uploaded_documents/southampton.pdf

Kabilan. M. K,. Ahmad, N., \& Zainol Abidin, M. J. (2010). Facebook: An online environment for learning of English in institutions of higher education?. Internet and Higher Education, 13, 179-187.

Kolek, E., \& Saunders, D. (2008). Online disclosure: An empirical examination of undergraduate Facebook profiles. Journal of Student Affairs Research and Practice, 45(1), 1-25. 
Kukulska-Hulme, A. (2007). Mobile Useability in Educational Contexts: What have We Learnt? International Review of Research in Open and Distance Learning, 8(2), 1-16.

Kukulska-Hulme, A., \& Shield, L. (2008). An overview of mobile assisted language learning: From content delivery to supported collaboration and interaction. ReCALL, 20(3), pp. 271-289.

Nadzrah, A. B., \& Mickan, P. (2003). Students' experiences in computer-based English language classroom. Proceedings of the 2003 ASIA CALL Conference. Gyeongju University, South Korea: ASIACALL.

Oduor, P. (2010). Kenya: How students use technology. KenyaCurrent, February 10, 2010. http://www.ictcradle.com/kenyacurrent/?p=836

Pachler, N. (2010). The socio-cultural ecological approach to mobile learning: an overview. Medienbildung in neuen Kulturräumen: Die deutschprachige und britische Diskussion, 153-167.

Pasfield-Neofitou, S. (2011). Online domains of language use: second language learners' experiences of virtual community and foreignness. Language Learning \&Technology, 15(2), 92-108.

Penrod, D. (2007).The next powerful step in 21st century learning. Lanham, MD: Rowman \& Littlefield Education.

Thornton, P. \& Houser, C. (2005). „Using mobile phones in English education in Japan“e Journal of Computer Assisted Learning, 21, (3): 217-228.

Raab, D. (2007). Use journaling to spark your writing. Writer 120(10), 30-33.

Rowen, D. (2005). The write motivation: Using the Internet to engage students in writing across the curriculum.

Learning \& Leading with Technology 32(5), 22-24.

Sharples, M. (Ed.) (2006). Big issues in mobile learning. Report of a workshop by the Kaleidoscope Network of Excellence Mobile Learning Initiative, University of Nottingham, UK.

Selwyn, N. (2009). Faceworking: Exploring students' education-related use of Facebook. Learning, Media \& Technology, 34(2), Thanawan Suthiwartnarueput, \& Punchalee Wasanasomsithi (2012). Effects of Using Facebook as a Medium for Discussions of English Grammar and Writing of Low-Intermediate EFL Students. Electronic Journal of Foreign Language Teaching 2012, Vol 9, No. 2, pp. 194-214. Retrieved 13 May 2013, from http://eflt.nus.edu.sg/v9n22012/suthiwartnarueput.pdf

Thornton, P. \& Houser, C. (2005). Using mobile phones in English education in Japan ${ }^{\text {ee }}$ Journal of Computer Assisted Learning, 21, (3): 217-228.

Teo, C. B., \& Gay, R. K. L. (2006). A knowledge-driven model to personalize e-learning. Journal on Educational Resources in Computing (JERIC), 6(1), 3.

Vygotsky, L. (1978). Mind in Society. London: Harvard University Press. Wilson, G. \& Stacey, E. (2004). Online interaction impacts on learning: Teaching the teachers teach online. Australasian Journal of Educational Technology, 20(1), 33-48. http://www.ascilite.org.au/ajet/ajet20/wilson.html

Woo, Y. \& Reeves, T. C. (2007). Meaningful interaction in web-based learning: A social constructivist interpretation. The Internet and Higher Education, 10(1), 15-25. http://dx.doi.org/10.1016/j.iheduc.2006.10.005 